University of Nebraska - Lincoln

DigitalCommons@University of Nebraska - Lincoln

December 2004

\title{
Federal Indian Law Internet Tools: Indian Territory Cases at the Oklahoma State Courts Network and Kappler's Indian Affairs: Laws and Treaties at the Oklahoma State University
}

Charles D. Bernholz

University of Nebraska-Lincoln, cbernholz2@unl.edu

Follow this and additional works at: https://digitalcommons.unl.edu/libraryscience

Part of the Library and Information Science Commons

Bernholz, Charles D., "Federal Indian Law Internet Tools: Indian Territory Cases at the Oklahoma State Courts Network and Kappler's Indian Affairs: Laws and Treaties at the Oklahoma State University" (2004). Faculty Publications, UNL Libraries. 9.

https://digitalcommons.unl.edu/libraryscience/9

This Article is brought to you for free and open access by the Libraries at University of Nebraska-Lincoln at DigitalCommons@University of Nebraska - Lincoln. It has been accepted for inclusion in Faculty Publications, UNL Libraries by an authorized administrator of DigitalCommons@University of Nebraska - Lincoln. 


\title{
Federal Indian law Internet tools: Indian Territory Cases at the Oklahoma State Courts Network and Kappler's Indian Affairs: Laws and Treaties at the Oklahoma State University
}

\author{
Charles D. Bernholz* \\ Love Memorial Library, University of Nebraska, Lincoln, NE 68588, USA
}

\begin{abstract}
In a thorough analysis of researching the regulation of the banking industry in the United States, Zoller (2000). Demonstrated a number of paths among federal documents of various agencies within the Department of the Treasury, including the legislation that created these entities, and to relevant online resources. This latter opportunity included electronic access to several traditional reporting vehicles: for example, the Congressional Record, Federal Register, Code of Federal Regulations, United States Code, Statutes at Large, and decisions from the U.S. Supreme Court. This leveraged ability to search among digitized versions of these materials has expedited research in the banking industry and has enhanced the chances to bring together for this area of study frequently scattered information. ${ }^{1}$ Further, with regard to the availability of such assets, the enhanced openness of this model is particularly important to Cornwell's (1996, p. 304). Concern that "no-fee access to government information would need to remain the cornerstone of any depository program."

This article reports a similar focused endeavor that involves the digital resources pertaining to treaties between the federal government and the American Indian tribes. It is a demonstration of the intersection of technology and of legal materials and data that have facilitated recent investigations of jurisprudence. (C) 2004 Elsevier Inc. All rights reserved.
\end{abstract}

Keywords: American Indian tribes; Internet; Legal materials

* Fax: +14024725131 .

E-mail address: cbernholz2@unl.edu. 


\section{Introduction}

Legal scholarship has flourished because materials long forgotten, or hidden in only a few libraries, have been digitized, and this effort has opened avenues for new investigations. Hoover (1991) presented an image a decade ago of what has now become a tidal wave of transformations, but some questions remain regarding the ability to rely exclusively upon these resources (Louis-Jacques, 2000).

A number of writers have commented recently on several dimensions of such electronic enterprises: on facets of, for example, agricultural (Geyer, 1998) or family law (Morgan, 2001); on changes to legal education induced by this technology (Goldman, 2001; Perritt, 1999); and on discussions of the development of virtual courtrooms (Heintz, 2002; Lederer, 1999).

Another particular corner of this scholarship that may be facilitated by electronic access is that of federal Indian law. Carter (2002) has noted the responsibility of law librarians to manage the growing array-and expanding demand for-materials in this area. Her suggestion that there is a "justification for increased attention to the third sovereign in American law libraries" (p. 26) requires a reassessment of collection development and of reference service. This new focus may be seen in the coordination of two Internet resources that lend support to an examination of federal Indian law in the Indian Territory at the turn of the twentieth century.

The Oklahoma State Courts Network (OSCN) provides access to an Indian Territory Cases site $^{2}$ on the World Wide Web. This location expedites searching of the Indian Territory Reports, a seven-volume compilation of cases determined by the United States Court of Appeals for the Indian Territory between February 1896 and September 1907 (Craig \& Kellogg, 1900-1909). ${ }^{3}$ This was one of the Territorial Courts that Congress created under Article I, Section 8, Clause 9 of the Constitution. ${ }^{4}$ With the admission of Oklahoma as a State on November 16, 1907, this court ceased to exist. ${ }^{5}$

Another important Internet site for federal Indian law is the Indian Affairs: Laws and Treaties database created by the Oklahoma State University (OSU) Library from Charles J. Kappler's collection of treaty and other legal materials. This digital collection ${ }^{6}$ permits access to each of the five volumes in this compilation. Volume 2 is particularly important because it contains the final text of almost every federally recognized treaty created between the various Indian Nations and the federal government (Kappler, 1904b). ${ }^{7}$

Taken together, these two resources can create a powerful legal research tool to facilitate a focused examination of the legal history of a unique region of the United States during its drive to Statehood. The tribal presence in this area, which resulted from the enforcement of the Indian Removal Act of 1830 (4 Stat. 411), ${ }^{8}$ led to many court cases that involved the treaties created with these entities. Following the Civil War, four new treaties ${ }^{9}$ were cast with the original Five Civilized Tribes that included, among other things, the provision for new courts. ${ }^{10}$ Creel (2002) has discussed the creation and implementation of these federal courts for Indian Territory. As Williams noted: "the government of the Indian Territory was anomalous, in that there was neither a local legislative body nor a local executive or governor, all laws being enacted by Congress. The people, other than the Indian tribes, were practically under the government of the judges of the United States courts in said 
Territory and the United States Indian Agent of the Union Agency at Muskogee" (1911, p. 135; emphasis added). Further, an examination of citations of Indian treaties within the opinions of any Territorial Court in the United States (Bernholz, 2004) revealed that almost one third of the opinions came from the United States Court of Appeals for the Indian Territory (created in 1895; 28 Stat. 693, 698), ${ }^{11}$ while a further $29 \%$ of the total number of actions were from the Supreme Court for the Territory of Oklahoma (initiated in 1890; 26 Stat. 81, 85).

\section{Application of the two databases}

Searching the OSCN Indian Territory Cases database for the stemmed term "treaty " generates an array of 40 cases before the United States Court of Appeals for the Indian Territory. In a correlated examination, 12 cases are returned by a search of this database for the occurrence of any Statutes at Large citation that contains at least 1 of the 10 specific volume numbers of the Statutes collection that contains Indian treaties. ${ }^{12}$

Inspection of the 40 case opinions obtained through the "treaty $\sim$ " examination reveals that only 17 cases actually refer to or cite directly one or more recognized treaties between the Indian Nations and the federal government. ${ }^{13}$ Eleven of the returned 12 Statutes at Large citation examples are among this selected set. ${ }^{14}$ The table identifies-within each of these 17 opinions - each unique direct reference or citation to a recognized treaty. There is a total of 48 citations made to 19 treaties. The individual treaties are denoted by the Ratified Treaty Number assigned to the instrument by the Department of State (Ratified Indian Treaties, $1722-1869,1966)$ and by the title of the document used by Kappler (1904b). Appendix A provides links to each of the 17 opinion texts on the OSCN Indian Territory Cases Web site. The electronic texts of each of the denoted treaty documents in Kappler's second volume ${ }^{15}$ contained in the OSU Indian Affairs: Laws and Treaties World Wide Web resource-are listed in Appendix B.

In this manner, direct access is available to the appropriate treaty text(s) of each Territorial Court case listed in Table $1 .{ }^{16}$ This advantage may be seen in the opinion of the final caseZevely $v$. Weimer - in which the opening paragraph of the electronic version states: "Under the treaty of 1855, art. 7 (11 Stat. 612), with the Choctaw and Chickasaw Nations, they were secured in the unrestricted use of self-government and jurisdiction of persons and property within their respective limits, excepting noncitizens, who were to be removed, with the exception of those trading therein under license from the proper authorities of the United States." ${ }^{17}$ Examination of the Treaty with the Choctaw and Chickasaw, 1855 text from OSU's Kappler collection ${ }^{18}$ reveals that this "unrestricted use" of self-government and jurisdiction is actually bound "[ins]o far as may be compatible with the Constitution of the United States and the laws made in pursuance thereof, regulating trade and intercourse with the Indian tribes." This constraint was amplified by Townsend, J., who stated in Zevely v. Weimer (5 Indian Terr. 646, 664 [1904]) that "The language is not that the Indian nations shall be secured in their jurisdiction over persons upon lands 'belonging to the tribe,' or 'which the 
Table 1

Cases from Indian Territory Reports that cited one or more Indian treaties before the United States Court of Appeals for the Indian Territory between February 1896 and September 1907 and corresponding Ratified Treaty Numbers of those treaties for each case

\begin{tabular}{|c|c|c|c|c|c|c|c|c|}
\hline \multirow{2}{*}{\multicolumn{2}{|c|}{$\begin{array}{l}\text { Case title } \\
\text { Ansley v. Ainsworth (1902) }\end{array}$}} & \multicolumn{7}{|c|}{ Ratified Treaty Number } \\
\hline & & \multirow[b]{2}{*}{160} & \multirow[b]{2}{*}{199} & \multirow[b]{2}{*}{220} & \multirow[b]{2}{*}{248} & \multirow[b]{2}{*}{292} & \multirow[b]{2}{*}{355} & \multirow[b]{2}{*}{358} \\
\hline $\begin{array}{l}4 \text { Indian Terr. } 308 \\
69 \text { S.W. } 884\end{array}$ & 115 & & & & & & & \\
\hline \multicolumn{9}{|c|}{ Ansley v. McLoud (1904) } \\
\hline $\begin{array}{l}5 \text { Indian Terr. } 563 \\
82 \text { S.W. } 908\end{array}$ & 292 & 355 & & & & & & \\
\hline \multicolumn{9}{|c|}{ Buster and Jones v. Wright (1904) } \\
\hline $\begin{array}{l}5 \text { Indian Terr. } 404 \\
82 \text { S.W. } 855\end{array}$ & 292 & 303 & & & & & & \\
\hline \multicolumn{9}{|l|}{ Dick v. Ross (1905) } \\
\hline $\begin{array}{l}6 \text { Indian Terr. } 85 \\
89 \text { S.W. } 664\end{array}$ & 248 & 358 & & & & & & \\
\hline \multicolumn{9}{|c|}{ Dukes v. Goodall (1904) } \\
\hline $\begin{array}{l}5 \text { Indian Terr. } 145 \\
82 \text { S.W. } 702\end{array}$ & 292 & 355 & & & & & & \\
\hline \multicolumn{9}{|c|}{ Dukes v. McKenna (1902) } \\
\hline $\begin{array}{l}4 \text { Indian Terr. } 156 \\
69 \text { S.W. } 832\end{array}$ & 292 & & & & & & & \\
\hline \multicolumn{9}{|c|}{ Glenn-Tucker v. Clayton (1902) } \\
\hline $\begin{array}{l}4 \text { Indian Terr. } 511 \\
70 \text { S.W. } 8\end{array}$ & 199 & 292 & 355 & 358 & & & & \\
\hline \multicolumn{9}{|c|}{ Hanks v. Hendricks (1900) } \\
\hline $\begin{array}{l}3 \text { Indian Terr. } 415 \\
58 \text { S.W. } 669\end{array}$ & 152 & 182 & 199 & 248 & & & & \\
\hline \multicolumn{9}{|l|}{ Ikard v. Minter (1902) } \\
\hline $\begin{array}{l}4 \text { Indian Terr. } 214 \\
69 \text { S.W. } 852\end{array}$ & 160 & & & & & & & \\
\hline \multicolumn{9}{|c|}{ Incorporated Town of Tahlequah v. Guinn (1904) } \\
\hline $\begin{array}{l}5 \text { Indian Terr. } 497 \\
82 \text { S.W. } 886\end{array}$ & 182 & 199 & 248 & & & & & \\
\hline \multicolumn{9}{|c|}{ Maxey v. Wright (1900) } \\
\hline $\begin{array}{l}3 \text { Indian Terr. } 243 \\
54 \text { S.W. } 807\end{array}$ & 11 & 126 & 292 & 303 & & & & \\
\hline \multicolumn{9}{|c|}{ McCurtain v. Grady (1896) } \\
\hline $\begin{array}{l}1 \text { Indian Terr. } 107 \\
38 \text { S.W. } 65\end{array}$ & 355 & & & & & & & \\
\hline \multicolumn{9}{|c|}{ Moore v. Girten (1904) } \\
\hline $\begin{array}{l}5 \text { Indian Terr. } 384 \\
82 \text { S.W. } 848\end{array}$ & 123 & 186 & & & & & & \\
\hline \multicolumn{9}{|c|}{ Muskogee National Telephone Co. v. Hall (1901) } \\
\hline $\begin{array}{l}4 \text { Indian Terr. } 18 \\
64 \text { S.W. } 600\end{array}$ & 303 & 356 & & & & & & \\
\hline $\begin{array}{l}\text { Tuttle v. Moore }(190 \\
3 \text { Indian Terr. } 712 \\
64 \text { S.W. } 585\end{array}$ & 356 & & & & & & & \\
\hline
\end{tabular}


Table 1 (continued)

\begin{tabular}{|c|c|c|c|c|c|c|c|c|}
\hline \multirow{2}{*}{\multicolumn{2}{|c|}{$\begin{array}{l}\text { Case title } \\
\text { United States v. Cohn (1899) }\end{array}$}} & \multicolumn{7}{|c|}{ Ratified Treaty Number } \\
\hline & & & & & & & & \\
\hline $\begin{array}{l}2 \text { Indian Terr. } 474 \\
52 \text { S.W. } 38\end{array}$ & 358 & & & & & & & \\
\hline Zevely v. Weimer & & & & & & & & \\
\hline $\begin{array}{l}5 \text { Indian Terr. } 646 \\
82 \text { S.W. } 941\end{array}$ & 96 & 124 & 126 & 160 & 220 & 292 & 355 & 364 \\
\hline
\end{tabular}

tribe is entitled to occupy,' but they express clearly and unmistakably that the authority of each nation shall be exercised throughout the entire territorial domain...." It is this level of clarification that may be attained through joint examination of these important historical legal resources now available on the World Wide Web.

\section{Table 1 and the Appendices}

Table 1 consists of the following data. For each of the 17 opinions, the title and the year of the case; the case citation in Indian Territory Reports; and the case citation in the South Western Reporter are listed. In addition, the appropriate Ratified Treaty Number, assigned by the Department of State to each instrument, identifies each treaty cited in the opinion of an individual court action.

Appendix A provides the uniform resource locator (URL) - for each of the 17 cases - in the OSCN Indian Territory Cases database.

Appendix B contains, for each of the 19 cited Indian treaties, the uniform resource locator (URL) in the OSU's Indian Affairs: Laws and Treaties electronic resource.

\section{Conclusions}

The efficacy of electronic government document resources has been discussed for a number of years. In particular, Aldrich (1996, p. 382) declared quite correctly that "[t]he rush to adopt the Internet as a primary dissemination conduit for federal government information portends a momentous change in the infrastructure through which Americans gain access to federal document information." Depository libraries must now adapt to these changes, balancing the need to preserve materials with the instantaneous accessibility expected by all patrons.

In addition, the Public Printer (James, 2004) has recently commented upon the evolution of the Government Printing Office's efforts to integrate government information with the World Wide Web. He remarked that the "GPO needs to work with its library partners to develop a new model for no-fee public access through the FDLP, which must include a fully digital database of all past, present and future U.S. Government documents, augmented database search and retrieval tools, and increased training to enable librarians to better serve the $21 \mathrm{st}$ century information needs of their patrons" (p. 3). ${ }^{19}$ 
Safai-Amini (2000) has examined the issue of Web-based information systems at the local government level. The general needs are identical to those at the federal level, but information sharing at the local level can leverage state and local agency data to facilitate Web-enabled usage by both state and local governments themselves, and their citizens. Certainly, the legal research links on the Oklahoma State Courts Network Web site (www.oscn.net) - including the very state-specific Indian Territory Cases-offer just such an opportunity.

State educational institutions complement this distribution process. The combination of the land-grant universities and the Federal and state depository programs provides additional avenues to better inform patrons. Chapman (1999) highlighted the interaction of land-grant university libraries and the federal programs that began in 1907 when Congress made these facilities depository libraries. ${ }^{20} \mathrm{He}$ stated, "Significant advances in the technological ability to transmit and disseminate electronic information bring an overwhelming array of government information from local, state, national, foreign, and international sources within a mouse click for individual users" (p. 385; emphasis added). The Oklahoma State University, as one of Oklahoma's land-grant institutions, has accomplished just this opportunity with their Indian Affairs: Laws and Treaties electronic resource. They have provided, as Chapman identifies (p. 399), "a more centralized and publicly accessible means of locating government publications for faculty, students, and, by extension, the citizens of their ... state." In this article's Federal Indian law example of the intersection of Indian treaties and cases before a unique court created by Congress in the process of forming the State of Oklahoma, the electronic databases created by both the Oklahoma State University and the Oklahoma State Courts Network reach beyond state boundaries. They enrich the opportunities of all citizens by "blurring" (Lippincott and Cheverie, 1999) the edges between the agencies. The efforts of these two state organizations serve as an excellent model for the development of future useful digital information suites created at the nonfederal level.

\section{Appendix A}

Cases from Indian Territory Reports that cited one or more Indian treaties before the United States Court of Appeals for the Indian Territory between February 1896 and September 1907 and the corresponding uniform resource locator (URL) for that case within the Oklahoma State Courts Network Web site.

\begin{tabular}{|c|c|}
\hline Case title & URL \\
\hline Ansley v. Ainsworth (1902) & http://www.oscn.net/applications/oscn/deliverdocument.asp?id=63175 \\
\hline Ansley v. McLoud (1904) & http://www.oscn.net/applications/oscn/deliverdocument.asp?id=63273 \\
\hline Buster and Jones v. Wright (1904) & http://www.oscn.net/applications/oscn/deliverdocument.asp?id=63262 \\
\hline Dick v. Ross (1905) & http://www.oscn.net/applications/oscn/deliverdocument.asp?id=63318 \\
\hline Dukes v. Goodall (1904) & http://www.oscn.net/applications/oscn/deliverdocument.asp?id=63298 \\
\hline Dukes v. McKenna (1902) & http://www.oscn.net/applications/oscn/deliverdocument.asp?id=63154 \\
\hline
\end{tabular}


Appendix A (continued)

\begin{tabular}{|c|c|}
\hline Case title & URL \\
\hline Glenn-Tucker v. Clayton (1902) & http://www.oscn.net/applications/oscn/deliverdocument.asp?id=63196 \\
\hline Hanks v. Hendricks (1900) & http://www.oscn.net/applications/oscn/deliverdocument.asp?id=63087 \\
\hline Ikard v. Minter (1902) & http://www.oscn.net/applications/oscn/deliverdocument.asp?id=63165 \\
\hline Incorporated Town of & http://www.oscn.net/applications/oscn/deliverdocument.asp?id=63268 \\
\hline \multicolumn{2}{|l|}{ Tahlequah v. Guinn (1904) } \\
\hline Maxey v. Wright (1900) & http://www.oscn.net/applications/oscn/deliverdocument.asp?id=63094 \\
\hline McCurtain v. Grady (1896) & http://www.oscn.net/applications/oscn/deliverdocument.asp?id=62906 \\
\hline Moore v. Girten (1904) & http://www.oscn.net/applications/oscn/deliverdocument.asp?id=63260 \\
\hline Muskogee National Telephone & http://www.oscn.net/applications/oscn/deliverdocument.asp?id=63110 \\
\hline \multicolumn{2}{|l|}{ Co. v. Hall (1901) } \\
\hline Tuttle v. Moore (1901) & http://www.oscn.net/applications/oscn/deliverdocument.asp?id=63135 \\
\hline United States v. Cohn (1899) & http://www.oscn.net/applications/oscn/deliverdocument.asp?id=63035 \\
\hline Zevely v. Weimer (1904) & http://www.oscn.net/applications/oscn/deliverdocument.asp?id=63281 \\
\hline
\end{tabular}

\section{Appendix B}

Treaty titles, arranged by Ratified Treaty Number, that were cited in the opinions of the cases listed in Appendix A from Indian Territory Reports before the United States Court of Appeals for the Indian Territory between February 1896 and September 1907, and the corresponding uniform resource locator (URL) for that treaty within the Indian Affairs: Laws and Treaties database created by the Oklahoma State University.

\begin{tabular}{|c|c|}
\hline Treaty title & URL \\
\hline $\begin{array}{l}\text { \# 11-Treaty with the } \\
\text { Cherokee, } 1785\end{array}$ & http://digital.library.okstate.edu/kappler/Vol2/treaties/che0008.htm \\
\hline $\begin{array}{l}\text { \# 96-Treaty with the } \\
\text { Quapaw, } 1818\end{array}$ & http://digital.library.okstate.edu/kappler/Vol2/treaties/qua0160.htm \\
\hline $\begin{array}{l}\text { \# } 115 \text {-Treaty with the } \\
\text { Choctaw, } 1820\end{array}$ & http://digital.library.okstate.edu/kappler/Vol2/treaties/cho0191.htm \\
\hline $\begin{array}{l}\text { \# 123-Treaty with the } \\
\text { Quapaw, } 1824\end{array}$ & http://digital.library.okstate.edu/kappler/Vol2/treaties/qua0210.htm \\
\hline $\begin{array}{l}\text { \# 124-Treaty with the } \\
\text { Choctaw, } 1825\end{array}$ & http://digital.library.okstate.edu/kappler/Vol2/treaties/cho0211.htm \\
\hline $\begin{array}{l}\text { \# 126-Treaty with the } \\
\text { Osage, } 1825\end{array}$ & http://digital.library.okstate.edu/kappler/Vol2/treaties/osa0217.htm \\
\hline $\begin{array}{l}\text { \# 152-Treaty with the } \\
\text { Western Cherokee, } 1828\end{array}$ & http://digital.library.okstate.edu/kappler/Vol2/treaties/che0288.htm \\
\hline $\begin{array}{l}\text { \# 160-Treaty with the } \\
\text { Choctaw, } 1830\end{array}$ & http://digital.library.okstate.edu/kappler/Vol2/treaties/cho0310.htm \\
\hline $\begin{array}{l}\text { \# 182-Treaty with the } \\
\text { Western Cherokee, } 1833\end{array}$ & http://digital.library.okstate.edu/kappler/Vol2/treaties/che0385.htm \\
\hline $\begin{array}{l}\text { \# 186-Treaty with the } \\
\text { Quapaw, } 1833\end{array}$ & http://digital.library.okstate.edu/kappler/Vol2/treaties/qua0395.htm \\
\hline
\end{tabular}


Appendix B (continued)

\begin{tabular}{|c|c|}
\hline Treaty title & URL \\
\hline $\begin{array}{l}\text { \# 199-Treaty with the } \\
\text { Cherokee, } 1835\end{array}$ & http://digital.library.okstate.edu/kappler/Vol2/treaties/che0439.htm \\
\hline $\begin{array}{l}\text { \# 220-Treaty with the } \\
\text { Choctaw and Chickasaw, } 1837\end{array}$ & http://digital.library.okstate.edu/kappler/Vol2/treaties/chi0486.htm \\
\hline $\begin{array}{l}\text { \# 248-Treaty with the } \\
\text { Cherokee, } 1846\end{array}$ & http://digital.library.okstate.edu/kappler/Vol2/treaties/che0561.htm \\
\hline $\begin{array}{l}\text { \# 292-Treaty with the } \\
\text { Choctaw and Chickasaw, } 1855\end{array}$ & http://digital.library.okstate.edu/kappler/Vol2/treaties/cho0706.htm \\
\hline $\begin{array}{l}\text { \# 303-Treaty with the } \\
\text { Creeks, etc., } 1856\end{array}$ & http://digital.library.okstate.edu/kappler/Vol2/treaties/cre0756.htm \\
\hline $\begin{array}{l}\text { \# 355-Treaty with the } \\
\text { Choctaw and Chickasaw, } 1866\end{array}$ & http://digital.library.okstate.edu/kappler/Vol2/treaties/cho0918.htm \\
\hline $\begin{array}{l}\text { \# 356-Treaty with the } \\
\text { Creeks, } 1866\end{array}$ & http://digital.library.okstate.edu/kappler/Vol2/treaties/cre0931.htm \\
\hline $\begin{array}{l}\text { \# 358-Treaty with the } \\
\text { Cherokee, } 1866\end{array}$ & http://digital.library.okstate.edu/kappler/Vol2/treaties/che0942.htm \\
\hline $\begin{array}{l}\text { \# 364-Treaty with the Kiowa } \\
\text { and Comanche, } 1867\end{array}$ & http://digital.library.okstate.edu/kappler/Vol2/treaties/kio0977.htm \\
\hline
\end{tabular}

\section{Notes}

1. The Department of the Treasury Web site-http://www.ustreas.gov/—provides extensive access to relevant banking and financial materials.

2. The URL for this site is http://www.oscn.net/applications/oscn/index.asp?ftdb=FDCSITandlevel=1.

3. As a demonstration of the limited availability of such useful materials, the OCLC WorldCat indicates that Indian Territory Reports are available at less than 150 member library sites worldwide.

4. Article I, Section 8, Clause 9 assigns the responsibility: "To constitute tribunals inferior to the Supreme Court." Congress responded with An Act to establish a United States court in the Indian Territory, and for other purposes, 25 Stat. 783 (1889). See the text at http://digital.library.okstate.edu/kappler/vol1/html_files/ ses0039a.html. Williams (1911) reviews the early development of the court systems in the six Indian Nations; the Indian, Oklahoma, and Cimarron territories; and the State of Oklahoma. Surrency (1987, pp. 345-360) presents a general discussion of U.S. Territorial Courts, and Burton (1995) offers a view of the court system within Indian Territory.

5. The final case in the last volume of Indian Territory Reports-Southwestern Development Co. v. Boyd (7 Indian Terr. 773; 104 S.W. 1174) - is dated September 26, 1907, and the opinion's sole footnote states, "Petition for rehearing filed October 8, 1907, and undisposed of when the court went out of existence November 16, 1907."

6. This collection is available at http://digital.library.okstate.edu/kappler/. Holcombe (2000) discusses OSU's efforts to bring this Kappler collection to the World Wide Web.

7. The Indian Affairs: Laws and Treaties set was produced between 1903 and 1941 . The treaty texts were published originally as Serial Set volume 4254 .

8. The measure's complete title was An Act to provide for an exchange of lands with the Indians residing in any of the states or territories and for their removal west of the river Mississippi.

9. The new treaties were the Treaty with the Seminole, 1866; the Treaty with the Choctaw and Chickasaw, 1866; the Treaty with the Creeks, 1866; and the Treaty with the Cherokee, 1866 (Kappler, 1904b, pp. 910-915, 918-931, 931-937, and 942-950, respectively). The latter three treaty citations were the ones referred to in 11 out of the 48 instances listed in Table 1. 
10. The Treaty with the Choctaw and Chickasaw, 1866 was cited by six cases, and section 8 of Article 8 of that treaty is representative of the language used in these four new instruments to formalize the creation of the courts: "The Choctaws and Chickasaws also agree that a court or courts may be established in said Territory with such jurisdiction and organization as Congress may prescribe: Provided, That the same shall not interfere with the local judiciary of either of said nations" (Kappler, 1904b, p. 922).

11. The initial case presented in Indian Territory Reports is Severs v. Northern Trust Co. (1 Indian Terr. 1; 35 S.W. 232 [1896]), decided on February 15, 1896.

12. The search element for this examination was the string: 7 Stat. OR 9 Stat. OR 10 Stat. OR 11 Stat. OR 12 Stat. OR 13 Stat. OR 14 Stat. OR 15 Stat. OR 16 Stat. OR 18 Stat.

13. There are several examples that illustrate how the initial 40 opinions were reduced by over half. Fraer v. Washington (4 Indian Terr. 165; 69 S.W. 835 [1902]) refers to the "Atoka treaty" and Scroggins v. Oliver (7 Indian Terr. 740; 104 S.W. 1161 [1907]) cites the same "Atoka Treaty of 1896" (Kappler, 1904a, pp. 646-656;) http://digital.library.okstate.edu/kappler/vol1/html_files/ses0646.html) as well as the "Supplemental Treaty of 1902" (pp. 771-787; http://digital.library.okstate.edu/kappler/vol1/html_files/ ses0771.html). These are both agreements concluded after March 3, 1871, the terminal date of treaty creation with the Indian Nations (16 Stat. 566). As a result, neither Fraer v. Washington nor Scroggins v. Oliver appears in Table 1. In a similar manner, the search for the "treaty " element in the OSCN Indian Territory Cases database returned Rowe v. Henderson (4 Indian Terr. 597; 76 S.W. 250 [1903]) because that case contains the phrase "Under the treaties and the laws of the United States" and the phrase "The very purpose of the treaties and the legislation of Congress..." Hockett v. Alston (3 Indian Terr. 432; 58 S.W. 675 [1900]) was identified through the phrase "... and was in conflict with the terms of the treaties between the Cherokee Nation of Indians and the government of the United States..." None of these occurrences identifies a definite treaty, so these and other cases containing unspecific treaty references were eliminated. Such imprecision is demonstrated further in the dissenting opinion of Clayton, J., in Buster and Jones v. Wright (5 Indian Terr. 404; 82 S.W. 855 [1904]): "The appellees, by their answers, rely upon the acts of Congress and the treaty of the United States with the Creek Nation, without naming them, and certain acts of the Creek Council" (emphasis added).

14. The twelfth case-United States v. Baker (4 Indian Terr. 544; 76 S.W. 103 [1903])—cites 18 Stat. 113 (part 3), An Act providing for publication of the revised statutes and the laws of the United States.

15. A Table that integrates all these data is available online, with the appropriate hyperlinks, at http:// www.unl.edu/bernholz/ITR.htm.

16. This is an interesting - and not a forgotten - suite of cases. All but four cases (Buster and Jones v. Wright, Dick v. Ross, Glenn-Tucker v. Clayton, and McCurtain v. Grady) have been cited before a State court. In Oklahoma jurisdictions, these 13 opinions have been cited a total of 26 times between 1901 and 1970, and there were an additional 22 citations in the courts of 16 other States and in the District of Columbia for the years 1903 through 1992. At the federal level and from 1902 until 1982, there have been 20 citations to seven of these territorial opinions before the U.S. Supreme Court, Courts of Appeals, and District Courts.

17. The Zevely $v$. Weimer opinion may be seen at http://www.oscn.net/applications/oscn/deliverdocument.asp?citeID $=63281$.

18. See http://digital.library.okstate.edu/kappler/Vol2/treaties/cho0706.htm for this treaty.

19. Note the appearance again of the "no-fee" access requirement, as noted earlier in Cornwell (1996). The Association of Research Libraries (Technology \& U.S. Government Information Policies, 1987, p. 28) was one early proponent to declare: "a system to provide equitable, no-fee access to basic public information is a requirement of a democratic society."

20. See An Act to amend an Act providing for the public printing and binding and the distribution of public documents (34 Stat. 1012, 1014): "And provide further, That all land-grant colleges shall be constituted as depositories for public documents, subject to the provisions and limitations of the depository laws." 


\section{References}

Aldrich, D. M. (1996). Depository libraries, the Internet, and the 21st century. Journal of Government Information, 23, 381-391.

Bernholz, C. D. (2004). American Indian Treaties in the Territorial Courts: A guide to treaty citations from opinions of the Territorial Court systems (in preparation).

Burton, J. (1995). Indian Territory and the United States, 1866-1906. Norman, OK: University of Oklahoma.

Carter, N. C. (2002). American Indians and law libraries: Acknowledging the third sovereign. Law Library Journal, 94, 7-26.

Chapman, B. (1999). The 1907 admission of land-grant university depository libraries: A 90-year perspective. Journal of Government Information, 26, 385-404.

Cornwell, G. T. (1996). The dissemination of federal government information: Prospects for the immediate future. Journal of Government Information, 23, 299-306.

Craig, J. F., \& Kellogg, F. H. (1900-1909). Indian Territory reports: Cases determined in the United States Court of Appeals for the Indian Territory. Parsons, KS: Foley Railway Printing Co.

Creel, V. (2002). A court of its own: The establishment of the United States Court for the Indian Territory. Oklahoma City University Law Review, 27, 231-244.

Geyer, L. L. (1998). The agricultural lawyers' guide to the Internet. Drake Journal of Agricultural Law, 3 , $63-101$.

Goldman, P. (2001). Legal education and technology: An annotated bibliography. Law Library Journal, 93, 423-467.

Heintz, M. E. (2002). Digital divide and courtroom technology: Can David keep up with Goliath? Federal Communications Law Journal, 54, 567-589.

Holcombe, S. L. (2000). Bringing Indian Affairs: Laws and Treaties to the World Wide Web. Available: http:// www.access.gpo.gov/su_docs/fdlp/pubs/proceedings/00pro11.html

Hoover, J. L. (1991). Legal scholarship and the electronic revolution. Law Library Journal, 83, $643-651$.

James, B. R. (2004). Keeping America informed in the 21st Century: A first look at the GPO strategic planning process - “A work in progress". Available: http://www.access.gpo.gov/su_docs/fdlp/pubs/proceedings/James. DLC.04192004.revised.pdf

Kappler, C. J. (1904a). Indian Affairs: Laws and Treaties: Vol. 1. Laws. Washington, DC: Government Printing Office.

Kappler, C. J. (1904b). Indian Affairs: Laws and Treaties: Vol. 2. Treaties. Washington, DC: Government Printing Office.

Lederer, F. I. (1999). Trial advocacy: The road to the virtual courtroom? A consideration of today's - and tomorrow's-high-technology courtrooms. South Carolina Law Review, 50, 799-844.

Lippincott, J. K., \& Cheverie, J. F. (1999). The "Blur" of federal information and services: Implications for university libraries. Journal of Government Information, 26, 25-31.

Louis-Jacques, L. (2000). Gaps in international legal literature. Chicago Journal of International Law, 1, $101-108$.

Morgan, L. W. (2001). Strengthening the lock on the bedroom door: The case against access to divorce court records on line. Journal of the American Academy of Matrimonial Lawyers, 17, 45-67.

Perritt, H. H. (1999). The Internet is changing the face of American law schools. Indiana Law Review, 33, $253-274$.

Ratified Indian treaties, 1722-1869. (1966). Washington, DC: National Archives and Records Service.

Safai-Amini, M. (2000). Information technologies: Challenges and opportunities for local governments. Journal of Government Information, 27, 471-479.

Surrency, E. C. (1987). History of the Federal Courts. New York: Oceana.

Technology and U.S. Government Information Policies: Catalysts for New Partnerships. (1987). Washington, 
DC: Association of Research Libraries.Williams, R. L. (1911). The judicial history of Oklahoma. Proceedings of the Fifth Annual Meeting of the Oklahoma State Bar Association (pp. 107-162). Oklahoma City, OK: Oklahoma State Bar Association.

Zoller, W. (2000). Researching US regulation of the banking industry through official publications. Journal of Government Information, 27, 559-579. 